\title{
« L'inscription phénicienne de Bodashtart in situ à Bustān ēš-Šēh (Sidon) et son apport à l'histoire du sanctuaire ». ZDPV, 121, 2005/2, pp. 119-129.
}

\section{Astrid Nunn}

\section{(2) OpenEdition}

1 Journals

\section{Édition électronique}

URL : http://journals.openedition.org/abstractairanica/16612

DOI : 10.4000/abstractairanica.16612

ISSN : 1961-960X

Éditeur :

CNRS (UMR 7528 Mondes iraniens et indiens), Éditions de l'IFRI

\section{Édition imprimée}

Date de publication : 15 mai 2007

ISSN : 0240-8910

\section{Référence électronique}

Astrid Nunn, « "L'inscription phénicienne de Bodashtart in situ à Bustān ēš-Šēh- (Sidon) et son apport à I'histoire du sanctuaire ». ZDPV, 121, 2005/2, pp. 119-129. », Abstracta Iranica [En ligne], Volume 28 | 2007, document 126, mis en ligne le 18 septembre 2007, consulté le 25 septembre 2020. URL : http:// journals.openedition.org/abstractairanica/16612 ; DOI : https://doi.org/10.4000/abstractairanica. 16612

Ce document a été généré automatiquement le 25 septembre 2020.

Tous droits réservés 


\section{« L'inscription phénicienne de Bodashtart in situ à Bustān ēššš̄h (Sidon) et son apport à l'histoire du sanctuaire ». ZDPV, 121, 2005/2, pp. 119-129.}

\section{Astrid Nunn}

1 La réédition des inscriptions phéniciennes du Liban et l'extraordinaire redécouverte d'une nouvelle inscription qui se trouvait près du sanctuaire de Bustān ēš-šēh (voir c.r. $\left.\mathrm{n}^{\circ} 127\right)$, a incité les épigraphes à de nombreux articles. Celui-ci réanalyse une inscription de Bodashtart qui n'est pas complètement inconnue mais pratiquement inédite. Cette épigraphe est la seule à se trouver encore in situ, sur le mur des inscriptions, soit sur la " première façade » à l'avant du podium. Bodashtart écrit qu'il a bâti un temple à son dieu Eshmoun. Évidemment la construction de ce temple est plus ancienne et remonte vraisemblablement au prédécesseur et cousin de Bodashtart, Eshmounazar II vers 550 av. J.-C. Mais Bodashtart réaménagea le podium (podium II). Il construisit aussi une seconde façade sur l'avant du podium. Les blocs, sur lesquels ses inscriptions étaient déjà écrites, avaient été insérés dans la (première) façade de manière à ne pas pouvoir être lus. Le roi aurait peut-être adopté cette coutume de Mésopotamie, où les textes et objets cachés dans des fondations sont connus depuis le III millénaire. La redécouverte de cette inscription aide aussi à établir la chronologie de la construction du sanctuaire sous Bodashtart. 
INDEX

Thèmes : 3.2.2. Pré-Achéménides et Achéménides

\section{AUTEURS}

ASTRID NUNN

Université de Munich 